\title{
THE INFL UENCE OF THE ECONOMIC CRISIS AND REFUGEE CRISIS ON EU POLITICS: THE CHALLENGES AND PROSPECTS FOR TURKEY-EU RELATIONS
}

Selcen ÖNER *

\section{Abstract}

This article focuses on the influence of the latest economic crisis and the Syrian refugee crisis on EU politics, increasing differentiation among the EU member states in terms of their interests and policies. It discusses the move towards further differentiated integration in the $E U$ and its influence on Turkey-EU relations. Firstly, it explains the influence of the economic crisis on European politics, particularly Germany's rising influence, the widening gap between northern and southern E urope, and B rexit referendum in the UK which led to discussions on further differentiated integration within the EU. Secondly, the article explains flexible integration models that were put forward before the economic crisis and it discusses new options for further differentiated integration after the economic crisis, refugee crisis and Brexit referendum. Lastly, the article evaluates the impact of refugee crisis on Turkey-EU relations, the revitalization of Turkey-EU relations, the rising role of Turkey as a 'strategic partner' of the EU and discusses the recent challenges and prospects in Turkey-EU relations.

Keywords: European Union, Turkey, economic crisis, refugee crisis, differentiated integration.

\section{D}

* Assoc. Prof. Dr., Bahçeşehir University, Faculty of Economics, Administrative and Social Sciences, Department of European Union Relations, e-mail: selcen.oner@eas.bau.edu.tr? 


\section{EKONOMIK KRİZIN VE MÜLTECİ KRİZININ AB SIYYASETINE ETKİSI: TÜRKIYYE-AB İLIŞKİLERİNDE ZORLUKLAR VE FIRSATLAR}

\section{$\ddot{O} z$}

Bu makalede ekonomik kriz ve Suriyeli mülteciler krizinin AB siyasetine etkisi ve üye ülkeler arasında çıkarlar ve politikalar açısından artan farklılaşma üzerinde durulmaktadır. AB içinde daha fazla farklılaştırllmış entegrasyona doğru gitme ĕ̆ilimi ve bunun Türkiye-AB ilişkilerine olan yansıması tartışllmaktadır. İlk olarak ekonomik krizin Avrupa siyasetine etkisi açıklanmakta, özellikle Almanya'nın artan nüfuzu, kuzey ve güney Avrupa arasında artan uçurum ve Ingiltere'deki referendum sonrası AB'de daha fazla farklılaştırılmış entegrasyon tartışmaları incelenmektedir. İkinci olarak, ekonomik kriz öncesi öne sürülen esnek entegrasyon modelleri değerlendirilerek ekonomik kriz, mülteci krizi ve Brexit referandumu sonrası daha fazla farklılaştırılmış entegrasyon için yeni seçenekler tartışlmaktadır. $M$ akalede son olarak da mülteci krizinin Türkiye- $A B$ ilişkilerine etkisi, TürkiyeAB ilişkilerindeki yakınlaşma, Türkiye'nin AB açısından giderek artan 'stratejik ortak’ rolü değerlendirilerek son dönemde Türkiye-AB ilişkilerindeki zorluklar ve firsatlar tartışılmaktadır.

Anahtar Kelimeler: Avrupa Birliği, ekonomik kriz, farklılaştırılmış entegrasyon, Türkiye, mülteci krizi.

\section{Introduction}

European integration has faced several crises throughout its history. Originating in the 2008 US mortgage crisis, the recent economic crisis is the biggest economic crisis since the Great Depression (Zahn, 2013: 5). As Moravcsik (2012: 54-58) argues, from the beginning 'the euro has rested on a gamble'. The crisis of the EU is not only economic, but there is also a political and identity crisis in the EU. Because of the lack of a strong common European identity among EU member states, the economically stronger member states are more hesitant to support the weaker ones. The extent to which solidarity among EU member states is sustainable in the face of economic crisis thus provides a good test case for the EU's future. The crisis has shown that reform and structural transformation are needed in the EU, specifically a more flexible 
?

institutional structure that can accommodate the diverse interests and expectations of both current and potential future members.

On the other hand, Europe's economic crisis has also had several other effects on European politics, mainly in the rising influence of far-right parties ${ }^{1}$ in several member states, as reflected in the last European Parliament (EP) elections in 2014. High unemployment rates, anxiety about the future and Socio-economic problems have led to the securitization of immigration, and may lead to a further decline in support for further EU enlargements.

The EU's economic crisis has led to doubts about its economic and social cohesion and its attractiveness, both for its citizens and for potential new members (Möller, 2012: 25). Both the EU and its member states have been focusing more on its internal problems, relegating enlargement to secondary importance (Keyman and Aydın-Düzgit, 2013: 2). There was already high level of scepticism towards Turkey's EU membership before the crisis, with Turkey being the least wanted country among current candidates due to perceived cultural and religious differences. Due to the economic crisis and resultant rising unemployment, Euroscepticism and enlargement scepticism have both risen in EU member states' publics, particularly when it concerns Turkey. Moreover, after the economic crisis, even less sceptical countries like Spain have become more hesitant about further enlargements. ${ }^{2}$

After the latest economic crisis there is a move towards a more 'differentiated integration' (Raik and Tamminen, 2014: 45). 'Differentiation' refers to the 'possibility of member states to have different rights and obligations with respect to common policy areas'. The literature of differentiation within the EU has focused on conceptualisation; however, less research has been done concerning its origins and its consequences (Kölliker, 2001: 127). Differentiation was not the concern of the European integration in the 1960s and 1970s. However, the debate between liberal intergovernmentalism and supranationalism which took place in the 1990s

\section{(1)}

${ }^{1}$ Various concepts are used for referring to far-right parties, such as 'radical right', 'populist', 'extreme-right', etc. (Mudde, 2007). Mudde (2014: 98-99) uses 'far-right' as an umbrella concept which includes both extreme-right and populist radical-right. The 'extreme-right' rejects democracy altogether, while radical-right accepts democracy but rejects liberal democracy, which includes pluralism and minority rights. In this article far-right is used.?

${ }^{2}$ For further detail, see Soler i Lecha, Eduard, 'Crisis and Decline in Southern Europe: Implications for Turkey', ifri Contemporary Turkey Programme, F ranco-Turkish Paper 8, July 2013.? 
when differentiation became an important future of European integration did not treat differentiated integration systematically neither (Holzinger and Schimmelfennig, 2012: 297).

The EU has been also facing with the refugee crisis which increased especially since 2015. The member states can not act in solidarity in this process. While Greece and Italy have had to deal with influx of irregular migrants, some member states of the EU such as Hungary resisted to accept refugees, rather build walls in its borders.

Turkey is hosting more than 2.5 million registered Syrian refugees. The Syrians were first received as 'guests' then they were subjected to a 'temporary protection' regime since October 2014 in Turkey. Although Turkey signed Geneva Convention in 1951, it maintains a geographical limitation to the application of the Geneva Convention, thus, Turkey gives refugee status only to asylum-seekers from Europe. There was a rise of irregular migration from Turkey especially to Greece in summer of 2015 which led to perceiving Turkey rather as a 'strategic partner'.

There has been a strategic rapproachment between the EU and Turkey in this context especially since the end of 2015. Because there is a necessity to collaborate with Turkey to deal with huge number of irregular migrants in the region.

This article focuses on the effects of the latest economic crisis and the refugee crisis on EU politics, its institutional structure, and evaluates the discussions on further differentiated integration. Moreover after the Brexit referendum in June 2016 in which the result is to leave the EU, the discussions on reforming the EU and more flexible integration models have come to the fore. In addition, this article evaluates how Turkey-EU relations will be influenced from all these processes.

Firstly, it explains the necessity for further differentiated integration with the influence of the economic crisis, refugee crisis and Brexit referendum. It emphasizes that while there is a move towards deeper integration among Eurozone countries, Britain decided to leave at Brexit referendum. Moreover the disparities among the member states have widened more after the refugee crisis especially since 2015. Secondly, it considers various models for the EU institutional structure that have been put forward and discusses the place of Turkey in these models. Lastly lack of solidarity and various approaches towards the refugee crisis among the member states led to the necessity for further cooperation with Turkey. In this article, the revival of momentum in 
?

Turkey-EU relations with the effect of the refugee crisis since late 2015, the move towards a more strategic approach and the challenges and prospects in Turkey-EU relations will be discussed.

\section{Widening Disparities within the $\mathrm{E} U$ after the $L$ atest $E$ conomic $C$ risis}

When the EU introduced the Euro convergence criteria for entering the Eurozone it failed to include any control mechanism about whether member states that no longer fulfilled the criteria should stay in the Eurozone or not (Majone, 2012: 12). According to McNamara (2010), no monetary union has succeeded without political union, including fiscal consolidation.

In October 2009, Greece admitted that it was no longer able to pay its creditors so, in February 2010, it was placed under budgetary supervision by the Commission. The EU and the International Monetary Fund (IMF) subsequently agreed a number of rescue packages, demanding that Greece stabilise and reform its public finances in return (Zahn, 2013: 8). Regarding the crisis, because of the risk that uncertainty over public finances would spread to other countries in the Eurozone, which happened by late 2011, Germany's Chancellor Angela Merkel pushed for the creation of a permanent bailout fund. The financial support between Eurozone countries was institutionalised through temporary European Financial Stability Facility and the permanent European Stability Mechanism, has been used since 2012. Establishing this required a new treaty, which was signed at the European Council Summit in March 2012. The Treaty on Stability, Coordination and Governance is also known as the Fiscal Compact, and was introduced to ensure national fiscal discipline. After Eurozone countries ratified the treaty, it came into force on 1 January 2013 (Glencross, 2013: 10-18). The Euro Plus Pact provides a political commitment between the Eurozone members and several non-Eurozone states, which came into force on 1 January 2014. This pact aimed to foster stronger economic policy coordination between these countries (Fabbrini, 2014: 10-13). With the introduction of these measures, the Eurozone core has been gradually moving towards a 'quasi-federation'. The 'Euro Plus Pact' countries represent a semiperiphery in the EU, which is closely associated with the Eurozone countries. Hungary and Sweden are not part of the Euro Plus Pact, but they signed the Fiscal Compact. The UK and the Czech Republic did not sign any form of binding policy coordination except for the annual European Semester, which is a loose policy coordination mechanism for non-Eurozone countries (Schweiger and Magone, 2014: 261). 
National leaders played a crucial role in arranging the terms of the bailouts, most prominently German Chancellor Angela Merkel, as leader of the Eurozone's major economic power. Many citizens of the member states requiring a bailout objected to the conditions imposed by other member states (Glencross, 2013: 9-19). Thus, national concerns have come to the fore and the EU's principle of solidarity has been negatively influenced.

In addition to Greece, bailout programmes were introduced for Ireland, Portugal and Cyprus, with strong conditions attached supervised by the Troika of the Commission, IMF and European Central Bank (ECB) (New Pact for Europe, 2013: 4). The 'ownership' of the Euro was thus taken by Eurozone states, who also took over political responsibility for its fate. Most of the "nonEurozone countries' have contributed to the rescue funds, although they have mostly refused to take political responsibility for Euro's future (Benes and Braun, 2014: 24). Thus, the gap between Eurozone and non-Eurozone countries has widened during this process in socio-economic terms, as also has the gap within the Eurozone countries. For example, while youth unemployment rates in July 2014 were lowest, at $7.8 \%$ in Germany, they were highest, at $53.8 \%$ in Spain (Schwarzer, 2014: 30).

The British Prime Minister, David Cameron, refused to sign the Fiscal Compact in 2011. Then, in 2013, he announced his intention, if re-elected in 2015, to re-negotiate the UK's terms of EU membership (Bloomberg, 2013, cited in Glencross, 2013: 17) and after that a referendum would be held for staying in or leaving the EU. He added that his preference was to remain in the EU. After his re-election in 2015, he confirmed his promises again and the referendum was held in the UK on 23 June 2016 and $52 \%$ of the voters preferred to leave the EU which shocked primarily the British people and the members of the EU. The leaving process will be based on Chapter 50 of the Lisbon Treaty, the negotiation process between the UK and the EU may approximately take up to 2 years which may be extended.

On the other hand, France and Germany have acted as the 'self-appointed nucleus' of the Eurozone's crisis management system in order to respond to weaknesses of the Eurozone's system of governance. However, the then president of France, Nicolas Sarkozy and Angela Merkel were perceived by many EU partners as dominant for bypassing joint EU and Eurozone institutions (Guerot and Klau, 2012: 2). Both France and Germany shared the goal of preventing the Eurozone breaking up and keeping Greece inside it. 
回

Merkel repeated several times that 'if the Euro fails, Europe fails' (Spiegel Online International, 2011).

During the crisis, the power balance between France and Germany moved in favour of Germany, which has the Eurozone's largest economy and is the biggest contributor to the EU budget. The bailout packages further increased Germany's influence within the EU, with the crisis leading to the emergence of a 'German Europe'. Growing unilateral German leadership has also led to a widening gap between northern and southern member states of the Eurozone (Fabbrini, 2014: 11). The dominant position of Germany will probably increase more after the Brexit referendum.

Thus, the necessity for further integration among Eurozone countries has become much clearer after the crisis and the citizens of the UK decided to leave the EU which led to a rise in debates on further 'differentiated integration' in the EU.

\section{Flexible Integration M odels for the $\mathrm{E} U$ before the $\mathrm{E}$ conomic $\mathrm{C}$ risis}

The Treaties of Paris (1952) and Rome (1958) are based on the principle of equal rights and obligations for all of the member states (Kölliker, 2001: 127). With the increase in heterogeneity of the member states caused by enlargement processes, the gap between member state preferences as well as their capabilities has widened. With the rise in the heterogeneity of the EU, there has been a rise in the necessity of differentiated in integration. The discussion on different models of differentiated integration started with the Tindemans Report (1976). The opt-outs and exclusions from EMU and Schengen, the establishment of the European Economic Area (1994), the bilateral agreements with Switzerland and the Customs Union with Turkey demonstrate that differentiated integration has already become an important feature of European integration especially since the 1990s (Holzinger and Schimmelfennig, 2012: 292-299).

The recent economic crisis has created a peripheral group of predominantly Southern European countries within the Eurozone that have become dependent on the financial support of other member states (Schweiger and Magone, 2014: 259). This has led to an increase in discussions on re-designing the EU's institutional structure, with more flexible arrangements. The recent Brexit referendum in the UK has further increased the discussions on reforming the EU and differentiated integration. 
Actually, flexibilisation is already being implemented in the EU, especially through the Amsterdam Treaty (1999) by introduction of 'enhanced cooperation' and it was strengthened with the Nice Treaty (2003). According to this option, countries that want further integration can continue deepening in certain policy fields, while others can stay outside. Meanwhile, the EU already has 'differentiated integration' in several policy fields, including the Eurozone, which does not include some members. The Schengen area also excludes some members, such as the UK and Ireland, who prefer to stay outside, while including some non-EU members, like Norway. In addition, the UK, Ireland and Denmark do not participate in all aspects of justice, freedom and security policies. Thus, the EU has developed an 'internally differentiated political system' (Dyson and Sepos, 2010, cited by Fabbrini, 2014: 8) that makes it possible to accommodate member states with different views on the 'finalite politique' of the integration process, and that have ability and interest to implement the EU policies at different speeds (Piris, 2012, cited by Fabbrini, 2014: 8). The primary common basis for members of the EU is the single market which acts as the 'glue that holds the EU together' (Corbett, 2014: 9). Brexit referendum shows that even this level of flexible integration within the EU has not been enough to satisfy heterogeneous members of the EU.

'Differentiated integration' is excluded for policies which are under the exclusive competence of the EU, such as trade policy. Instead, it has usually been used in policy areas like the common currency, justice, freedom and security. However, these types of differentiated forms of integration are perceived only as a strategy of 'last resort' for European integration, when EU members cannot all agree on desired objectives within a reasonable time. The Treaty of Lisbon introduced several 'new opt-outs, including a protocol partially exempting the UK and Poland from the Charter of Fundamental Rights'. Von Ondorza (2013: 5-14) argues that differentiated integration is the only way of realizing the deeper integration needed to overcome Europe's economic crisis.

First proposed at the end of the 1960s, the idea of 'differentiated integration' has been developed since then and transformed into new forms. Stubb (1996) classified differentiated integration in three ways: The first is temporal differentiation such as two or multi-speed Europe, the second one is territorial differentiation such as 'Europe of Concentric Circles' and the third one sectoral differentiation such as 'variable geometry' and 'Europe a la carte'(Holzinger and Schimmelfennig, 2012: 296). 
囵

In March 2006, before the economic crisis, the EP adopted a report on the EU's future enlargement strategy, including the idea of a European Economic Area (EEA)+', involving the creation of a European free trade zone and further cooperation in the Common Foreign and Security Policy (CFSP). Norway, Ukraine, Albania, Montenegro, Croatia, Bosnia and Herzegovina, Serbia, Macedonia, Kosovo and Belarus were mentioned as possible candidates for EEA + and, if membership negotiations fail, Turkey (Karakaş, 2013: 10641068). According to Benes and Braun (2014: 18) this type of 'multi-tier collaboration' could facilitate enlargement in the long-term. That is, if EEA countries are viewed as one tier of collaboration, then candidate countries could become part of this tier before gaining full EU membership. As von Ondorza argues (2013: 7-13), differentiated integration is challenging for EU cohesion because some member states do not participate in certain policy fields, risking the development of a split in the EU. For this reason, most of the non-Eurozone members voluntarily contributed to EU financial assistance programs and the Fiscal Compact to prevent the risk of division between Eurozone countries and other member states. In reality, though, the EU is already splitting into three groups. The first includes those Eurozone countries involved in all the rescue and reform measures during the crisis plus those receiving financial support, although even this group is actually split between the providers of financial support and the recipients. The second includes countries such as Poland that are legally obliged and politically committed to joining the Eurozone when ready. Within this group there is variation in terms of countries' willingness to participate in Euro crisis management and their desire for deeper economic policy integration. The last group includes permanent outsiders with opt-outs, such as UK and Denmark, plus Sweden, which has a de facto 'opt-out' by avoiding legal obligations by not fulfilling the criteria to enter the Eurozone.

The paradigm of a 'multispeed Europe' can be traced back to Willy Brandt and Leo Tindemans, who formulated this model in the mid-1970s. According to this model, some member states will progress more quickly towards integration of specific policy fields, with the ultimate goal being 'supranational federalism'. A 'two-speed Europe' can be perceived as a sub-type of a 'multispeed Europe' (Schauble and Lamers, 1994; cited in Karakaş, 2013: 1063).

The paradigm of 'Europe a la carte' was formulated at the end of the 1970s by Ralf Dahrendorf. This paradigm takes an intergovernmental approach in which the member states retaining freedom of choice regarding their participation in various policy fields (Dahrendorf, 1979; cited in Karakaş, 2013: 
1063). In this model, member states only share some basic common objectives, such as the single market (von Ondarza, 2013: 8).

The paradigm of a 'variable geometry Europe' was introduced at the beginning of the $1980 \mathrm{~s}$ by the French government. In this paradigm, the Commission and certain EU founding members act as the driving force behind integration. This allows those member states that want further integration to progress, while those that integrate more slowly lose the right to participate in decision-making. Flexibility can be included within treaties or arranged outside them. Non-member states can also be included in the integration process, though without decision-making rights (Commissariat General du Plan, 1980; cited in Karakaş, 2013: 1064). 'Concentric circle Europe' can be considered as a sub-concept of this paradigm (CEPR 1995; cited in Karakaş, 2013: 1064). The emergence of the EEA in addition to EU member states is an example of 'variable geometry Europe'.

Since the economic crisis, with the widening gap between Eurozone and non-Eurozone members and especially after the Brexit referendum, these models have come to the fore again, which may influence Turkey-EU relations.

\section{Differentiated Integration in the EU and The Case of Turkey's Membership}

In European integration history it was assumed that deepening and enlargement were mutually compatible. Indeed, EU enlargement has not prevented deepening; rather, it has triggered institutional reforms and led to the introduction of new treaties (Schimmelfennig, 2014: 11).

The economic crisis has had a relatively marginal influence on EU enlargement in economic terms because financing this has little impact on the EU's budget. Western Balkan countries, some of which are official candidates, and some of which have already started negotiations, are relatively small so their influence on future EU budgets will also not be so much. On the other hand, Turkey's accession would be more costly (Kral, 2010: 1-4). In addition, there is already 'enlargement fatigue' in the EU. As Kral (2010: 1-5) argues, the economic crisis may strengthen the scepticism of both the public and political leaders in EU member states towards further enlargements, especially in Germany, as the biggest contributor to the EU budget. ${ }^{3}$ The determination of

\section{(1)}

${ }^{3}$ According to the previous budget term (2007-2013) there are 12 net contributors to the EU budget, that receive less money from the EU then they pay to the budget. According to the European Commission, the largest net contributors include Germany ( 9 billion 
回

the EU to include Western Balkan countries is viewed as a duty for a region that had suffered from war in the former Yugoslavia in the 1990s. In Turkey's case, however, there has never been such rhetoric facilitating accession. As Kral (2010: 4-5) argues, Germany's support has always been crucial for the EU enlargements. Furthermore, as the biggest economy in Europe, its importance has become much greater for further enlargements after the economic crisis.

The biggest challenge for Turkey's accession is the Cyprus issue. Although Turkey signed the Additional Protocol, it has not implemented it yet by opening its harbours and airports to Greek Cypriot transport because the EU has not fulfilled its promise after the Turkish Cypriots' acceptance of the Annan Plan to end their isolation because of the veto of Greek Cypriots in the EU. Currently 16 chapters have been opened out of 33 and 16 were blocked. On the other hand, there are still crucial deficiencies, especially concerning freedom of speech and freedom of media in Turkey, which have also negatively influenced the accession process of Turkey.

Due to the economic crisis, discussions have increased about redesigning the EU's institutional structure. ${ }^{4}$ The EU's internal transformation will also have crucial implications for Turkey's accession process. Therefore, Turkey should follow and engage more in this debate about the EU's future institutional structure.

The Commission President Jean Claude Juncker, stated that EU enlargement would remain a low priority during his term in office, while assuring that no further enlargement will take place in the coming five years during his presidency. ${ }^{5}$ His policy guidelines thus indicate that the EU will be more cautious in the coming years in terms of enlargement. Most probably, the EU will take into account its internal dynamics and concerns more in this process, particularly its 'absorption capacity', for future enlargements. Juncker did not mention Turkey in his statements regarding the enlargement process; rather, he emphasized the accession process of the Western Balkan countries (Turhan,

W W W W

Euros), France ( 6.4 billion), Italy (5.9 billion), the UK (5.6 billion) and the Netherlands (2.2 billion).?

${ }^{3}$ For further detail, see E Fuat Keyman, and Senem Aydın-Düzgit, 'Transforming Turkey-EU Relations: Ground for Hope', Global Turkey in Europe, Policy Brief 6, March 2013; Meltem Müftüler-Baç, 'The Future of Europe, Differentiated Integration and Turkey's Role', Global Turkey in Europe, Commentary 9, October 2013; Kemal Derviş, 'Turkey and Europe, A New Perspective', Policy Brief 3, November 2012.? ${ }^{4}$ For further detail, see 'My Foreign Policy Objectives", http://juncker.epp.eu/sites/def ault/filesattachments/nodes/en_03_fp.pdf? 
2014: 5). Moreover, the Juncker Commission has changed the Directorate General (DG) Enlargement to the DG European Neighbourhood Policy and Enlargement Negotiations which shows that the European Neighbourhood Policy (ENP), rather than enlargement will be the priority in the medium-term.

Before the economic crisis, 'privileged partnership' was proposed as an alternative to full membership by Germany's Christian Democrats, supported by French and Austrian conservatives, although this was immediately rejected by Turkey. The Negotiation Framework Document for Turkey (2005) mentioned the possibility of 'permanent derogations' in areas like free movement of people, structural funds and agricultural funds. Thus, Turkey could be excluded from important policy fields even if it became an EU member (Karakaş, 2013: 1066-1068). In fact, Turkey is already a 'privileged partner' of the EU, especially since it became a member of the Customs Union in 1996, while the proposal of 'privileged partnership' would run against the principle of pacta sunt servanda.

The 'gradual integration/membership model' was also put forward in 2005. This envisages the gradual thematic integration of Turkey with the EU. The realization of each integration level would depend on mutual willingness and Turkey's successful implementation of political and economic reforms. There could be further integration in trade relations, CFSP and justice, freedom and security issues. This model proposes establishing an 'extended council' in which Turkey could also participate as an equal partner. In this council, Turkey would have 'sectoral decision-making rights' for integrated areas, but no right of veto. The 'Positive Agenda' ${ }^{6}$ between the EU and Turkey may be considered as an example of one step in this model. However, Turkey does not have any decision making rights within the Positive Agenda, which is not considered as an alternative to the ongoing negotiations; rather, it aims to improve relations between Turkey and the EU in policy fields like immigration and visas (Karakaş, 2013: 1069-1070).

As Soler i Lecha (2013: 22) argues, the economic crisis has reduced both the EU's attractiveness and its 'transformative power' over Turkey. The crisis has also economically and politically weakened Turkey's supporters, such as Spain. In Germany and Austria, with large numbers of Turkish immigrants, public opinion was strongly against granting Turkey EU membership, even before the crisis. The economic crisis has further increased anti-enlargement sentiment

\section{m}

${ }^{5}$ Because of the stalemate in negotiations, Turkey and the EU decided to deepen their relations through the introduction of the Positive Agenda in May 2012.? 
国

across Europe. Accordingly, differences between the Eurobarometer results of 2012 and 2008 show that the greatest increases in opposition to further enlargements can be seen in Ireland (+14\%), Spain (+14\%) and Portugal (+9\%). On the other hand, opposition to further enlargements in these countries is still much lower than in Austria (91\%) and Germany (78\%) (cited in Soler i Lecha, 2013: 8-15).

In spite of its economic crisis, the EU is still Turkey's most important trading partner, and the accession process remains crucial for Turkey in terms of encouraging freedom of speech and the media and improved living standards. As Derviş (2012: 2-4) argues, Turkey would still benefit from EU membership, in spite of the latter's economic crisis, particularly because it would contribute to remedying Turkey's democratic deficiencies, particularly freedom of media, strengthen Turkey's influence regionally and contribute to the long-term stability of the Turkish economy.

While differentiated Europe may solve the EU's 'political stagnation', it may lead to fragmentation, which can be one of the main challenges for differentiation. As Stubb (2014: 84-87) argues, 'differentiation is not an objective in its own right, but a tool for effective enlarging and deepening of the EU'.

Joschka Fischer, who is the former German Minister of Foreign Affairs, suggested 'complete reconstruction of the EU' which should include core Eurozone members, with the rest participating in various policy fields in accordance with their interests and capacity to integrate (Zeit Online, 2011; cited in Avbelj, 2013: 191). The former French President Sarkozy, spoke in favour of creating a 'two-speed Europe', in which the core is Eurozone countries and the rest will stay in a loose confederation attached to the core (The Economist, 2011; cited in Avbelj, 2013: 191).

Müftüler-Baç (2013: 1-3) proposes three alternative scenarios for the EU's future. The first is a 'federal supranational state', which she sees as the least likely scenario. Second, the EU could remain mostly intergovernmental. The third scenario is 'differentiated integration', which involves a 'core group' of EU members that transfer most of their competencies to the EU while other EU members choose among common policies and participate in those that they prefer. As she argues, the EU's evolution towards 'differentiated integration' could provide it with several opportunities for further deepening, which may facilitate further enlargements because newcomers, particularly Turkey, can be involved in the specific policy fields that they wish to and can adapt to. 
Another model is 'concentric circles'. This option has been revived after the recent crisis. In this model, while Eurozone members move in a more federalist direction, a more flexible outer circle develops, consisting of non-Eurozone members that participate in the single market. According to Tocci and Bechev (2012: 4), if the EU moves towards this structure, it will be easier for Turkey to become a member of the outer circle. It would also ease the accession of Western Balkan countries. However, this scenario could face resistance from Turkey and other potential members of the outer circle that may consider this as 'second-class membership'. According to Soler i Lecha (2013: 23), 'Turkey could play a less controversial role in a more flexible, different shaped Europe'. One example of the various forms of 'differentiated integration' is the customs union agreement between Turkey and the EU in which Turkey does not have decision-making power, but only rights to information. To secure the implementation of EC association regulations, the EU-Turkey Association Council was established to take decisions in order to implement the provisions of the Ankara Agreement (1963). Thus, the customs union is a kind of de facto partial membership since Turkish foreign trade policy becomes determined by the EU. However, Turkey cannot participate in the EU's decision-making system which has created several economic challenges for Turkey. There have been ongoing negotiations about revising the customs union between Turkey and the EU. In addition to being part of the customs union, Turkey participates in programmes for research and development, culture and education. At its own request, Turkey also participates in some of CFSP and EU police and military missions, particularly in the Balkans, although here again it cannot join in decision making (Karakaş, 2013: 1064-1065). In short, Turkey already has a special relationship with the EU that represents more than just an associate membership.

Keyman and Aydın-Düzgit (2013: 4) argue that the ideal form of membership for Turkey could involve joining the EU's political and security institutions and single market while remaining outside the Eurozone and the Schengen area. This would create a 'flexible mode of full membership' different from that of the core member states. They suggest that a 'flexible full membership model', similar to those of Sweden and Poland ${ }^{7}$, who are part of

\section{(1)}

${ }^{6}$ Sweden has a special position in terms of adopting the Euro. To adopt Euro, a country needs to be part of the Exchange Rate Mechanism II for 2 years, but Sweden has decided not to participate in this mechanism, which gives Sweden a de facto 'opt-out' from the Eurozone. Poland has not participated in Eurozone yet either, but, according to 
回

the Schengen but outside the Eurozone, would be more suitable for Turkey. However, there is a fear about Turkey's participation in the Schengen area. A long transition period before joining the Schengen area may be introduced in order to overcome the fears about influx of immigrants from Turkey.

Another model is 'virtual membership', in which a 'virtual member' would adopt only part of the EU acquis while intergovernmental cooperation would prevail in external and internal security policies. A 'virtual member' would be granted only observer status in most EU institutions. Such a model, if applied to Turkey's case, could decrease Turco-scepticism in the EU even more than the model of a concentric circle Europe (Tocci and Bechev, 2012: 4). Ülgen (2012: 1-13) argues that virtual membership for Turkey would complement the accession process, allowing a less than complete adoption of the EU acquis and a less influential role in EU decision making than member states. As Ülgen argues, Turkey is already a 'virtual member state', because it has been an associate member of the EU and part of the Customs Union, while participating in several programmes like Erasmus after gaining official candidate status at the Helsinki Summit in December 1999. Thus, a 'deeper association membership framework' may be established for Turkey, which would have a more intergovernmental character. Ülgen (2012: 26-28) emphasizes that it is a framework for policy convergence that can supplement the accession process. He suggests that it would allow Turkey's membership bid to be postponed to a time when the EU is more ready to integrate it. Through this model, Turkey and the EU can further cooperate in various policy fields while the negotiations continue and may learn how to act together in different policy fields, which may facilitate Turkey's integration into the EU.

Finally, Tocci and Bechev (2012: 5) propose the 'multiple cluster spaghetti bowl' model for the EU which proposes two cores: 'core 1 is for economic governance and core 2 is for foreign policy'. Core 1 might develop along federalist lines, while core 2 could become intergovernmental. Eurozone members would remain part of core 1 while core 2 would include the UK and Turkey. After the Brexit referendum this model needs to be redesigned. The negotiations between the UK and the EU need to be followed by Turkey and the cooperation model between the UK and the EU may be taken as a model by Turkey which may be used during the accession process. Because of the o its Treaty of Accession, it has to participate in the Eurozone once it fuilfills its requirements.?

${ }^{7}$ It was first proposed in the 1990s for the Western Balkans and revived in discussions on the European Neighbourhood Policy.? 
principle of 'pacta sunt servanda', the EU cannot easily renege on its promises of eventual full EU membership for Turkey.

Thus, flexible integration models in the EU have come to the fore since the latest economic crisis because of the necessity to establish further integration among Eurozone members, respond to the widening gap between Eurozone members and non-Eurozone member states, and Brexit referendum. This consideration of flexible integration models may facilitate Turkey's integration process, because such models would allow Turkey to remain outside several policy fields, such as the Eurozone, while participating in certain other fields. Flexible integration models can also facilitate further enlargements. Through gradually cooperating and integrating across several policy fields, it would be easier to integrate the new members.

As a result, 'differentiated integration' which already exists in the EU can be constructed as 'unity in differentiated integration', inspired by the EU's motto of 'unity in diversity'. There are already different integration levels within the EU among its member states, with the single market, trade policy and competition policy acting as the common foundation for the member states. Optional policies may be restricted to certain policy fields, such as monetary union and Schengen, while security and defence policies are already intergovernmental. Member states can thus participate in decision making for the policy fields that they participate in; for those policy fields that they do not participate they can be informed and consulted. The main challenge for the EU is to establish and maintain coherence within such a differentiated structure.

\section{Turkey's Increasing Role as a 'Strategic Partner' of the EU after the R efugee C risis}

In December 2013, the EU-Turkey readmission agreement was signed and simultaneously the EU started a visa liberalization dialogue with Turkey. These agreements foresee the lifting of visa requirements for Turkish citizens in threeand-a-half years if Turkey can fulfil the criteria in the roadmap. ${ }^{9}$ The roadmap includes 72 criteria in the fields of documents security, migration and border management, public order and security and fundamental rights. The

\section{(1)}

${ }^{8}$ For further detail, see Cemal Karakaş, (2013) "EU-Turkey: Integration without Full Membership or Membership without Full Integration? A Conceptual Framework for Accession Alternatives", J ournal of Common M arket Studies, (51) 6: 1071.

9 "EU-Turkey Readmission Agreement signed and Visa Liberalization Dialogue launched", 16 December 2013, http://ec.europa.eu/dgs/home-affairs/what-isnew/news/news/2013/20131216_01_en.htm? 
?]

readmission agreement has applied since October 2014. It applies to Turkish citizens but Turkey negotiated three year delay before it applies to nationals of the other countries.

The civil war in Syria has created one of the worst humanitarian crisis in this century. The number of asylum seekers is the highest in number after the $2^{\text {nd }}$ World War. With the effect of the increasing influx of irregular migrants especially to Greece, the EU wanted to accelerate the implementation of the readmission agreement by Turkey for third country nationals.

The Dublin system puts a disproportionate amount of pressure on the member states which are located at external borders of the EU such as Greece and Italy. The temporary relocation system introduces a new distribution key model which allocates responsibility between member states on the basis of new criteria which include GDP, population and unemployment. On the basis of the Commission's initiative the member states adopted a Resolution on relocating certain number of asylum seekers from Greece and Italy in 2015. However, only some of the member states such as Sweden and Finland actively participated in this relocation system (Carrera et.al., 2015: 5-13). On 14 September 2015 the Czech Republic, Slovakia, Hungary and Romania opposed the relocation of the refugees among the EU members in Justice and Home Affairs Council. Thus, mainly two camps emerged within the EU in this respect: the first camp is led by Germany who has been trying to reach a communitarian deal and the second camp which includes primarily Hungary is looking for an intergovernmental solution to this issue (Toygür and Özsöz, 2016: 8). Juncker (President Juncker, 2016) during his speech at the EP stated that "we cannot abandon any member state to face the crisis alone. A country's place on the map should not determine its share of the work to be done".

Turkey as the key transit country emerged as a critical player in managing the flow of refugees to Europe. German Chancellor Angela Merkel visited Istanbul on 1 November 2015 and met with Turkish President Tayyip Erdogan and decided to revitalize the accession talks in return for the Turkish commitment to act as a gatekeeper for the Syrian refugees (Müftüler-B aç, 2015: 3-6).

Two extraordinary Turkey-EU summits were held on 5 October and 29 November 2015, both on the request of the EU (Carrera et.al., 2015: 7-8) These summits were the first summits of the European Council with a candidate country. Merkel clearly stated Europe's need for Turkey's collaboration in the refugee crisis. Turkey currently hosts more than 2.7 million registered Syrian 
refugees and more than seven billion Euro has been already spent by Turkey in order to provide humanitarian aid and support to these people (Managing the refugee crisis, 2016). After the meeting on 29 November 2015 EP President Martin Schulz stated that 'the crisis situation we find ourselves in today which is a realy eye-opener on how interdependent we already are, will lead to a fresh start in EU-Turkey relations. This is not cooperating just for technical reasons or temporary circumstantial reasons. EU-Turkey relations must be a long-term strategic choice.'

In the EU-Turkey Joint Action Plan (2015) it was stated that the EU and Turkey will address this crisis together in a spirit of burden sharing. Three billion Euro was allocated by the EU for Turkey for the next two years in order to provide funds for the projects for the refugees who are under temporary protection in Turkey. The plan promises to open the blocked negotiation chapters. It also proposed to implement earlier the readmission agreement with the EU in exchange for visa liberalisation for Turks. This plan was an important turning point for perceiving Turkey by the EU as a strategic partner and border guard of the EU. Thus, Turkey promised to support 'managing irregular migration' for leverage over the EU, while expecting visa liberalization for its citizens, getting financial support for the projects related with the refugees in Turkey and opening negotiation chapters (Kale, 2016). Chapter 17 on Economic and Monetary Policy was opened in December 2015.

According to Joint Action Plan, the refugee crisis would be solved with Turkish support with financial and administrative assistance of the EU but outside its territories (Müftüler-Baç, 2015: 6). Although this plan was criticized for humanitarian reasons, it provides an opportunity to revitalize relations particularly in the fields of strengthening border controls and security cooperation. Thus, it was a turning point towards a realistic security-oriented perspective in Turkey-EU relations (Kale, 2016: 3).

On the other hand, the EU has been criticized for losing its leverage toward Turkey in recent years with respect to its normative power on encouraging democratic reforms (Kale, 2016). Especially in recent years particularly after the refugee crisis EU is moving towards a 'Fortress Europe' rather than a 'value-based community' (Toygür and Özsöz, 2016: 8).

On 18 March 2016 Turkey and the EU agreed to continue taking measures against migrant smugglers and welcomed establishment of NATO activity on the Aegean Sea. Some of the main components of this agreement are: All irregular migrants crossing from Turkey into Greek islands as from 20 March 
?

2016 will be returned to Turkey. It was emphasised that it will take place in full accordance with EU and international law. The costs of the return operations of irregular migrants will be covered by the EU. For every Syrian being returned to Turkey from Greek islands another Syrian will be resettled from Turkey to the EU. The fulfilment of the visa liberalisation roadmap will be accelerated in order to lift the visa requirements for Turkish citizens at the latest by the end of June 2016, if all the benchmarks will be done by Turkey. However this deadline could not be realized. In addition to these, it was decided that the EU in close cooperation with Turkey will further speed up the disbursement of the allocated three billion Euro under the Facility for Refugees in Turkey. Once these resources will be used and provide its commitments EU will mobilise additional funding for the facility of an additional three billion Euro up to the end of 2018. In addition to these the EU and Turkey reconfirmed their commitment to reenergise the negotiations, they decided to open chapter 33 on budgetary and financial provisions during the presidency of Netherlands which was opened in June 2016 before the ending of the Dutch Presidency.

This agreement corresponds to the needs of the EU in combating irregular migration, rather than burden sharing; it tries to externalize the issue beyond its borders (Paçacı Elitok, 2015). This agreement was criticised mainly on the basis of perceiving Turkey's role as decreasing the number of asylum seekers who can reach European countries.

\section{Conclusion}

The recent economic crisis, the refugee crisis and the Brexit referendum have been crucial challenges in the history of the European integration project. These challenges have triggered the necessity for the reform of the EU. The goals of the EU project and construction of European identity in the context of the EU need to be discussed and re-evaluated in this context.

The economic crisis has indeed made the EU's political and economic fault lines more apparent, particularly between Europe's north and the south and between countries inside and outside the Eurozone (Glencross, 2013: 3). There is still a risk that the gap between the core and the periphery may further widen (Möller, 2012: 27). As Moravcsik (2012: 67-68) argues, the economic crisis 'will shape not just the fate of the single currency but also the future of the whole continent'. The crisis has enabled cooperation in certain policy fields to be deepened, such as the introduction of monetary and banking regulation. On the other hand, rising unemployment rates and the refugee crisis especially since the summer of 2015 have increased social problems, and increased 
xenophobia and scepticism towards immigrants and refugees. There has also been a rise in the level of support for far-right parties, far-right movements while Euroscepticism and enlargement scepticism have also grown in EU member states.

The EU's credibility and attractiveness has decreased significantly with the economic crisis, not only among its citizens but also in its neighbourhood and globally (Möller, 2012: 27) which negatively influence its transformative power. However, as Moravcsik (2012: 68) argues, 'even a collapse of the Euro would not jeopardize the existence of the EU', although it seems that it is too difficult for the EU to evolve into a European federal state, as this already failed when the Constitutional Treaty was rejected in 2005 (Avbelj, 2013: 210). The goal of establishing a federal Europe has been further challenged with the rising disparities after the refugee crisis and especially after the Brexit referendum, the EU will most probably lead to a further differentiated integration.

Although the EU's transformative power over Turkey has been declining, it still has a crucial influence on Turkey, especially concerning the rule of law and freedom of the media. Neither Turkey nor the EU wants to lose each other because of their mutual interests, including security, energy security, geostrategic concerns and especially the necessity for the support of Turkey has risen for the EU after the rising influence of refugee crisis in Europe.

The policies of Germany and France concerning Turkey's membership have had a strong influence on Turkey's accession process, especially Germany's influence within the EU increasing a lot with the economic crisis and the refugee crisis. Thus, Germany's policies towards Turkey's accession to the EU will have a stronger influence on Turkey's future relationship with the EU. In France, following a change in President, there have been several relatively positive signals regarding Turkey's accession. The chapter on regional policy was opened in November 2013. For now, it seems that both Germany and France are in favour of continuing the negotiations and strengthening cooperation with Turkey in various fields while maintaining their scepticism about granting full membership.

The EU's recent socio-economic and political challenges require redesigning its institutional structure to 'reconcile its widening and deepening'.

\section{(1)}

"EU-Turkey Readmission Agreement signed and Visa Liberalization Dialogue launched", 16 December 2013, http://ec.europa.eu/dgs/home-affairs/what-isnew/news/news/2013/20131216_01_en.htm 
?

The option of further 'differentiated integration' has come to the fore especially after the economic crisis, which has been perceived as 'a means of managing diversity between the member states’ (Avbelj, 2013: 209). As Derviş (2012: 4) argues, Turkey has to develop its own ideas and proposals on the future institutional structure of the EU and its role within it. He argues that if Turkey becomes an EU member, its status may therefore be similar to the UK's. After the UK's decision to leave at the Brexit referendum, the UK's negotiations with the EU and how their relations with the EU will be formulated needs to be analysed well. As Müftüler-Baç (2013: 2-3) argues, 'differentiated integration' with Turkey would include deepening the Customs Union, which may include increased cooperation in the financial sector. In addition, there could be increased cooperation in the CFSP, which would lead to Turkey's membership of the European Defence Agency and the participation of the Turkish Minister of Foreign Affairs in relevant Council meetings. Further cooperation and integration in the fields of foreign policy, migration and asylum policies and economy, particularly revising the Customs Union albeit without participating in the Eurozone may gradually lead to full membership in the longer term.

As an associate member, Turkey already has a 'privileged partnership' with the EU because of being part of the Customs Union since 1996 and participating in many EU programmes. The Positive Agenda provides a framework for further cooperation between Turkey and the EU in different policy fields such as foreign and security policy and migration while continuing negotiations. Turkey should closely follow evolution of the EU's institutional structure and contribute to discussions about the EU's future and Turkey's place within the EU. Turkey needs to create a new rhetoric and policy to accelerate its integration process to the EU.

The introduction of visa liberalization may thus revive the negotiations between Turkey and the EU. If the visa liberalisation can be realised a new concrete common goal of Turkey and the EU can be introduced which may facilitate gradual integration of Turkey to the EU. However, there is still an ongoing problem of lack of mutual trust between Turkey and the EU in spite of the strategic rapprochement with the effect of the refugee crisis.

The factors that will continue to influence the future of Turkey-EU relations include, firstly, the Cyprus issue, and secondly, the political will of member states, particularly the policies of France and especially Germany towards Turkey's membership bid. The third factor concerns the impacts of Brexit referendum on future of the EU, while the fourth factor concerns Turkey's 
domestic situation and its reform process, particularly in the fields of rule of law and freedom of media. If there will be any change in the conjuncture, particularly if there will be a compromise in the Cyprus issue, the momentum of the negotiations may be revived. Finally, not only the changes within the EU, but also global developments and internal developments in Turkey will influence Turkey-EU relations.

Consequently, with the effect of the latest economic crisis, lack of solidarity after the refugee crisis and the Brexit referendum, EU may lead to a further 'differentiated integration'. However, the EU also needs to prevent the emergence of a growing gap between its north and the south, or core and periphery (The Report of Heinrich Böll Stiftung, 2011: 12). The EU's goal thus needs to be establishing 'unity in differentiated integration', inspired by its motto of 'unity in diversity'.

There is a move towards a more pragmatic and strategic approach in Turkey-EU relations. Since late 2015 'realpolitik has taken over the valuebased anchor of EU membership...Turkey EU relationship has developed into a kind of geostrategic partnership rather than a value-based alliance' (Toygür and Özsöz, 2016). In the Commission document (2016: 2) about the operational steps in EU-Turkey cooperation in the field of migration it was stated that 'these joint efforts to deal with refugees are part of our global engagement with Turkey as candidate country and as strategic partner'. However both sides need to act on the basis of EU norms and humanitarian principles. This is also crucial for the credibility of the EU.

There is still a lack of mutual trust between Turkey and the EU. The agreement between Turkey and the EU in order to cope with refugee crisis is short-sighted. In order to introduce a sustainable solution to this situation, there is a necessity for burden sharing among EU member states, solidarity principle needs to be implemented among them, while Turkey and the EU need to go on cooperation. In addition to these, the EU needs to cooperate with the countries in the neighbouring regions and the Syrian crisis has to be solved as soon as possible.

Several scenarios may be put forward about the future institutional structure of the EU and Turkey's place in it. First, Turkey may become a member like Sweden which was put forward by (Keyman and Aydın-Duzgit, 2013), which is a member of the Schengen area, but outside the Eurozone. The EU may not be in favour of this because one of the EU's main fears is involving Turkey in the Schengen area. However, a long transition period could be introduced for 
圆

Turkey in this policy field. In the second scenario, Turkey may become part of the EEA+. However, the EU may be sceptical about this scenario as it also includes the free movement of people. Turkey, too, may be sceptical since it would not gain participation in the EU's decision-making system, which is similar to the idea of 'privileged partnership' and against the principle of 'pacta sunt servanda'. In the third scenario, in intergovernmental fields, such as CSDP, Turkey could participate in decision-making, while staying outside the Schengen area and the Eurozone. In other policy fields, there could be an extended association between Turkey and the EU. However, this may be also considered as a second-class membership for Turkey. Lastly the type of relationship that was developed between the UK and the EU after the Brexit referendum needs to be followed and analysed well. During the negotiation process, these scenarios may be discussed more to discover complementary instruments and frameworks to the negotiation process to establish further cooperation between Turkey and the EU.

The economic crisis, the refugee crisis and lastly the result of the Brexit referendum have led the EU to focus more on its internal problems, rather than further enlargements; on the other hand, it has led to discussions on further 'differentiated integration' within the EU. Thus, during the negotiation process, Turkey needs a new rhetoric and policies towards the EU. Turkey needs to follow carefully the evolution of the EU's institutional structure, political and economic developments in the EU and its member states, further engage in debates about its future structure and discover how it can participate in the institutional structure that eventually emerges and how it can contribute to the EU's goals including maintaining peace and security in the region.

As a result, various cooperation and communication frameworks between Turkey and the EU may help overcoming the biggest problem of lack of mutual trust between the two parties and they may help revival of the momentum of the negotiations, while encouraging Turkey's gradual integration into the EU which is not only a win-win solution for both parties, at the same time this is crucial for peace of the region and to fight against common challenges such as fighting against terrorism and dealing with the refugee crisis. 


\section{References:}

Avbelj, M. (2013) "Differentiated Integration: Farewell to the EU-27?", German Law J ournal, 14 (1).

Benes, V. and Braun, M. (2014) "An Ever-Closer Eurozone and Its Consequences for Differentiated Integration in Europe", in Blockmans, S. (ed.), Differentiated Integration in the EU: From the Inside Looking Out, (Brussels: Centre for European Policy Studies).

Communication from the Commission to the European Parliament, the European Council and the Council: 'Next Operational Steps in EU-Turkey Cooperation in the Field of Migration', 16 March 2016, Brussels.

Carrera, S. et.al. (2015) “The EU's Response to the Refugee Crisis Taking Stock and Setting Policy Priorities", CEPS essay, 16 December 2015, No. 20.

Corbett, R. (2014) "Two-tier Europe: Really?", in Blockmans, S. (ed.), Differentiated Integration in the EU: From the Inside Looking Out, (Brussels: Centre for European Policy Studies).

Derviş, K. (2012) “Turkey and Europe, A New Perspective”, Global Turkey in Europe, November 2012, Policy Brief 3.

EU -Turkey Joint Action Plan (2015).

EU -Turkey Statement, Press Release, 18 March 2016, Brussels.

Fabbrini, S. (2014) "After the Euro Crisis: A New Paradigm on the Integration of Europe", April 2014, Arena Working Paper 5.

Glencross, A. (2013) "The EU Response to the Eurozone Crisis: Democratic Contestation and the New Fault Lines in European Integration", July 2013, Europa-Kolleg Hamburg Institute for European Integration, Discussion Paper 3.

Guerot, U. and Klau, T. (2012) "After Merkozy: How France and Germany can Make Europe Work", May 2012, European Council on Foreign Relations, Policy Brief 56.

Holzinger, K. and Schimmelfennig, F. (2012) "Differentiated Integration in the European Union: Many Concepts, Sparse Theory, Few Data", J ournal of European Public Policy, 19 (2).

Kale, B. (2016) "The EU-Turkey Action Plan is Imperfect, but also Pragmatic and maybe even Strategic", February 2016, The German Marshall F und of the U nited States on Turkey. 
回

Karakaş, C. (2013) “EU-Turkey: Integration without Full Membership or Membership without Full Integration? A Conceptual Framework for Accession Alternatives", J ournal of Common Market Studies, 51 (6).

Keyman, E. F. and Aydın-Düzgit, S. (2013) "Transforming Turkey-EU Relations: Ground for Hope", March 2013, Global Turkey in E urope, Policy Brief 6.

Kral, D. (2010) "The Impact of the Economic Crisis on EU Enlargement and Eastern Partnership", Europeum, Institute for European P olicy, 1 November 2010, <http://www.europeum.org/doc/pdf/910.pdf>, (15 October 2013).

Kölliker, A. (2001) "Bringing Together or Driving Apart the Union? Towards a Theory of Differentiated Integration", West European Politics, 24 (4).

Majone, G. (2012) "Rethinking European Integration after the Debt Crisis", June 2012, London's Global U niversity The European Institute, Working Paper 3.

Managing the Refugee Crisis: The Facility for Refugees in Turkey, The Commission Document, Brussels, 2016.

McNamara, K. (2010) "The Eurocrisis and the Uncertain Future of European Integration", September 2010, Council on Foreign Relations, $<$ http://www.cfr.org/world/eurocrisis-uncertain-future-europeanintegration/ p22933>, (18 November 2013).

Moravcsik, A. (2012) "Europe after the Crisis: How to Sustain a Common Currency”, F oreign Affairs, May-June, 91 (3).

Möller, A. (2012) "Crossing Borders or Introvert Union? The Euro Crisis and the EU's Relations with Its Southern Neighbors", Europe, Turkey and the Mediterranean. Fostering Cooperation and Strengthening Relations, Europe in Dialogue 3, Bertelsmann Stiftung.

M üftüler-Baç, M. (2015) "The Revitalization of the Turkish-European Union Relations: Old Wine in New Bottles?", December 2015, IPC-MERCATOR Policy Brief.

Müftüler-Baç, M. (2013) “The Future of Europe, Differentiated Integration and Turkey's Role”, October 2013, Global Turkey in Europe, Commentary 9.

New Pact for Europe (2013) "Strategic Options for Europe's Future", December 2013, B russels. 
Paçacı Elitok, S. (2015) "A Step Backward for Turkey? The Readmission Agreement and the Hope of Visa Free Europe", December 2015, IPC Mercator Policy Brief.

"President Juncker: Europe needs a Genuine Security Union" (2016), European Commission News, 13 April 2016, <http://ec.europa.eu/news/2016/04/2016 0413_en.htm>.

Raik, K. and Tamminen, T. (2014) "Inclusive and Exclusive Differentiated Integration: Enlargement and the European Neighbourhood Policy", in J. Jokela (ed.), M ulti-speed Europe?: Differentiated Integration in the External Relations of the $E U$, The Finnish Institute of International Affairs Report, No 38.

Schimmelfennig, F. (2014) "Enlargement and Integration Capacity: A Framework for Analysis", February 2014, Free University of Berlin MAXCAP Working Paper Series, No 1.

Schulz, M. (2015) Speech by Martin Schulz at Informal Summit between the EU and Turkey, 29 November.

Schwarzer, D. (2014) "Strengthening the Euro Area", Challenge Europe, Issue 22, Challenges and New Beginnings: Priorities for the EU's New Leadership, European Policy Centre, Brussels.

Schweiger, C. and Magone, J. M. (2014) "Introduction: Differentiated Integration and Cleavage in the EU under Crisis Conditions", Perspectives on European Politics and Society, 15 (3).

Soler i Lecha, E. (2013) 'Crisis and Decline in Southern Europe: Implications for Turkey', July 2013, ifri Contemporary Turkey Programme, F rancoTurkish Paper 8.

Spiegel O nline International (2011) “ 'If the Euro fails, Europe fails': Merkel Says EU Must be Bound Closer Together”, 7 September, $<$ http://www.spiegel.de/international/germany/if-the-euro-fails-europe-failsmerkel-says-eu-must-be-bound-closer-together-a-784953.html>,(12 October 2013)

Stubb, A. (2014) "Differentiated Europe Needs Strong Institutions", Challenge Europe, Issue 22, Challenges and New Beginnings: Priorities for the EU'S New Leadership, European Policy Centre, Brussels.

Stubb, A. (1996) "A Categorization of Differentiated Integration", J ournal of Common Market Studies, 34 (2). 
?

The Report of the Heinrich Böll Stiftung (2011) Publication Series on Europe, Vol.6, "Solidarity and Strength: The Future of the European Union", Belgium.

Tocci, N. and Bechev, D. (2012) "Will Turkey Find Its Place in Post-Crisis Europe?", December 2012, G lobal Turkey in Europe, Policy B rief 5.

Toygür, İ. and Özsöz, M. (2016) "Reshaping Relations in the Midst of Crises: A Bitter Anniversary for Turkey-EU Accession Negotiations", IPCMERCATOR Policy Brief.

Turhan, E. (2014) "After the 2014 European Parliament Elections: What is at stake for Europe and Turkey-EU Relations?", September 2014, IPCMERCATOR Policy Brief.

Ülgen, S. (2012) “Avoiding A Divorce: A Virtual EU Membership for Turkey”, December 2012, The Carnegie Papers, Washington.

Von Ondarza, N. (2013) "Strengthening the Core or Splitting Europe?: Prospects and Pitfalls of a Strategy of Differentiated Integration", M arch 2013, German Institute for International and Security Affairs SWP Research Paper, Berlin.

Zahn, R. (2013) "European Enlargement and the Economic Crisis: Impact and Lasting Effects", ETUI, Working Paper 1. 